\title{
The Service of Documents in Administrative Procedural Law - A Comparative Analysis ${ }^{1}$
}

\author{
Ines Golob \\ Dravograd Administrative Unit, Slovenia \\ ines.golob@gov.si
}

\section{ABSTRACT}

This article presents a comparative and empirical analysis of the service or the delivery of documents in procedures, as the key procedural action to constitute legal effects in legal relationships. In Slovenia, service is largely defined by the three main procedural laws - the General Administrative Procedure Act, the Criminal Procedure Act, and the Contentious Civil Procedure Act. These relate to different types and specifics of relationships; for instance, in administrative proceedings, the public interest prevails over private ones. The presented research, applying predominantly normative and comparative methods and analysis of case law, aims to show the importance of the specificity of the different areas and of the rules of service in different proceedings. The results of the research suggest that in certain cases service should be regulated in a uniform manner. Yet the specific aims of various legal relations require individual solutions. Thus, the article opens up grounds for future comparative research and practical regulatory improvements.

Keywords: administrative procedure law, case law, serving documents, procedural delivery, comparative analysis, Slovenia

$J E L: K 19$

\section{Introduction}

Service - seen as a procedural action ${ }^{2}$ - is one of the most important institutions of any procedure: if service is not effected properly, the act is not final/ enforceable. In Slovenia, the legal relationships between an individual party and the Government are regulated according to the procedures prescribed by the relevant procedural laws. The research presented in this article includes a

1 The article is a summary of the master's thesis of Ines Golob: Analiza vpogleda v spis in vročanja v upravnih, kazenskih in pravdnih postopkih [An analysis of access to the file and delivery in administrative, criminal and civil procedures] (https://repozitorij.uni-lj.si/IzpisGradiva.php?id=90898), prepared under the mentorship of Prof. Polonca Kovač, PhD, and defended at the Faculty of Administration of the University of Ljubljana on 11 July 2016.

2 See Breznik et al., 2008, Jerovšek et. al., 2004. 
comparison of the systems of service under the three most important procedural laws - the General Administrative Procedure Act (hereinafter: the ZUP), the Criminal Procedure Act (hereinafter: the ZKP), and the Contentious Civil Procedure Act (hereinafter: the ZPP). Despite the differences concerning the method of service, all three procedural laws have a significant influence on the legal relationships between different actors and contribute to legal certainty in the country.

Procedural law is an extremely demanding legal field with a considerable impact on the parties involved in legal proceedings. The systemisation of law is necessary in particular to regulate individual narrower and broader units of law within a single system, thereby contributing to transparency of law. All legal areas together constitute the national legal system applying in a specific country. However, each legal area has its own peculiarities, which are reflected both in substantive law and in procedural laws governing a certain legal area. Typical examples of procedural law in Slovenia include criminal procedure law, civil procedure law, and administrative procedure law ${ }^{3}$.

In their work, administrative bodies in Slovenia apply several procedural rules when deciding on rights, obligations, legal benefits, or other legal statuses of the parties. Administrative bodies primarily operate under the ZUP, the courts mainly apply the ZKP, the Minor Offences Act, the ZPP and the NonContentious Civil Procedure Act, while other state bodies also apply special regulations adapted to their specific proceedings (e.g. the Tax Procedure Act in financial matters).

Administrative law is primarily applied by those public administration bodies that decide on internal affairs, social security, health care, environment and spatial planning, education, agriculture, etc. The general administrative procedure is a legally regulated sequence of actions aimed at establishing a relationship under administrative law. This relationship differs from other legal relationships since it arises on the basis of a unilateral and authoritatively declared will of a representative of the public interest. In the process of establishing this relationship, parties are not equal as the representative of the public has stronger powers (Jerovšek et al., 2004, p. 36).

Criminal law is applied by state authorities dealing with criminal offences defined under substantive criminal law. According to the widespread belief, criminal law has two basic functions: to protect and to guarantee. In its protective aspect, criminal law protects the fundamental social values that are articulated in the modern times primarily as human rights and fundamental freedoms. / ... / The basic means by which criminal law exercises its protective function is repression or, more simply, punishment. /... / In its guarantee function, criminal law provides individuals with protection against the possible arbitrary, unlawful and inhumane acts of the state repressive apparatus (Turk et al., 2004, p. 73).

3 See Selinšek, 2007, Ude et al., 2005. 
Civil law covers the legal norms governing property relations between equal entities on the basis of the dispositive principle; the violation of these norms implies property sanctions. Civil law is divided into substantive and procedural law / ... / Substantive law provides which and what rights and obligations can exist between individual legal entities, while procedural law regulates how and before which authority these rights and obligations are enforced (Toplak, 2002, p. 17).

The institution of service under a particular procedural law is regulated specifically for the legal area in question, hence the differences between individual procedural laws. Service in Slovenia is therefore a rather complicated issue. In certain proceedings, the elements and systems of service provided under different procedural laws intertwine, which leads to errors in the work of the competent authorities and to a lack of understanding of the provisions on service among the parties in the proceedings.

The article examines the systems of service under the three main procedural laws - ZUP, ZKP and ZPP - and compares the various elements of service provided therein to find similarities and differences. When serving a document, an official person must choose the appropriate manner of service which depends on the type of document being served (whether the document gives rise to certain legal consequences for the party), on the party's request concerning service (service to be effected electronically, personally, on an authorised person, etc.), on the party's location (abroad, in prison, etc.), on whom the document is to be served (natural person, state authority, legal person, attorney, etc.), and other reasons.

The aim of the article is to present the differences of service under a particular procedural law and the consequences of a particular regulation for the parties in the proceedings through the empirical analysis of the relevant judgements of the Supreme Court of Slovenia.

By means of a normative and comparative analysis, the article first examines the different manners of serving and the similarity and differences between individual procedural laws. Later on, an empirical analysis of the relevant judgements of the Supreme Court between 2013 and 2016 is provided. The judgements of the Supreme Court represent unified case law, thus ensuring judicial protection of an individual or other entity against authoritative decisions of the administration. For the sake of interpretation of this article, it is important to know that in deciding in administrative matters, the Supreme Court has different powers than, for example, in a criminal or civil proceeding where it acts as a third-instance body i.e. a body that decides after extraordinary legal remedies have been exhausted. The main research question is the comparison of the different manners of serving and the resulting advantages and disadvantages thereof. In this context, the article investigates the hypothesis that the elements and systems of service under different procedural laws intertwine, which leads to errors in the work of the competent authori- 
ties and to a lack of understanding of the provisions on service among the parties in the proceedings, as stated in the abstract.

\section{Overview of Literature and Procedural Law Characteristics of Service in Slovenia}

In Slovenia, service is regulated by various procedural laws and in various manners. As a rule, the administrative authorities in Slovenia effect service under the ZPP, the ZKP, and the ZUP. Certain administrative authorities serve under specific laws: financial offices serve pursuant to the Tax Procedure Act (ZDavP-2), while courts in certain cases follow the Court Register of Legal Entities Act (ZSReg) and the Financial Operations, Insolvency Proceedings and Compulsory Winding-up Act (ZFPPIPP).

The forms and manners of service are further affected by other laws, such as the Postal Services Act (ZPSto-2), which in Chapter VII prescribes that postal items are delivered in accordance therewith or in accordance with other laws.

Recently, electronic service is coming to the fore. Such manner of serving is partly regulated by the Electronic Business and Electronic Signature Act (ZEPEP), providing that electronic signature is equivalent to the physical signature of the party.

Since Slovenia is a member of the EU, it must also take into account Regulation (EC) No. 1393/2007 of the European Parliament and of the Council of 13 November 2007 on the service in the Member States of judicial and extrajudicial documents in civil or commercial matters.

According to Kovač, service, although an extremely important issue in a democracy, is often underestimated in practice. The serving (at least fictitious) of an act by an authority is a precondition for the arising of legal consequences, yet the manner of serving can be limited (e.g. service only by public notification or on an authorised person) (Kovač, 2013, p. 219).

Below is a presentation of some of the most important manners of service and a comparison between individual procedural laws.

\subsection{Personal serving}

All documents that in any way affect legal certainty, give rise to legal consequences, from the serving of which a time limit begins to run, or are relevant for the party to become acquainted with the procedure and the decision of an authority, must be served personally on the person for whom they are intended. ${ }^{4}$ Personal serving means that a document is served on the addressee

4 If the person that should accept a document refuses to do so without any legally provided reason, the server shall leave the document in the apartment where such person lives or on the premises where they are employed, or shall affix the document on the door of the apartment or premises or leave it in a letterbox. If service is effected in the manner referred to in the preceding paragraph, the server shall write on the proof of service the day, the hour and 
directly or personally. However, the addressee may explicitly authorise another person to take over the document on his or her behalf. Personal serving is possible both physically and electronically into a secure mailbox of the addressee (more in Kovač \& Remic, 2008).

Jerovšek and Kovač suggest that service is the key procedural action, because it is a prerequisite for the creation of legal effects of the document being served. Until served, it is deemed that an act has not yet been issued (in the sense of creation of legal consequences in relation to the parties or other addressees and the issuing authority) (Jerovšek \& Kovač, 2010, p. 114).

Similarly, Androjna and Kerševan argue that the service of a document has important legal consequences for the document to be served, for the authority issuing the document, and for the person to whom the document is served or intended. A decision "issued" in an administrative proceeding that has not been notified or pronounced orally does not give rise to any legal effect until it is dispatched or served on the party. Legally speaking, a decision that has not been served on the party does not yet exist - hence, it is not binding neither for the party nor for the body that formulated the content thereof. Therefore, before it is served on the party, the decision is considered an internal act and can still be changed or withdrawn by the issuing body (Androjna \& Kerševan, 2006, p. 227).

the reason for the refusal of acceptance, as well as the place where they left the document; service shall thereby be deemed effected. (ZUP, Art. 95) 
Table 1: Personal serving

\begin{tabular}{|c|c|}
\hline $\begin{array}{c}\text { Procedural } \\
\text { law }\end{array}$ & To be served personally \\
\hline $\begin{array}{l}\text { ZUP } \\
\text { Art. } 87\end{array}$ & $\begin{array}{l}\text { Decisions and procedural decisions as well as other documents } \\
\text { from the serving of which a time limit begins to run must be } \\
\text { served on the person for whom they are intended. }\end{array}$ \\
\hline $\begin{array}{c}\text { ZKP } \\
\text { Art. } 120-121\end{array}$ & $\begin{array}{l}\text { Documents are to be served personally: } \\
\text { - on the defendant (a summons to the first interrogation in } \\
\text { pre-trial procedure and a summons to the main hearing), } \\
\text { - on the defendant who has not retained defence counsel } \\
\text { (the indictment, the judgement, all decisions for which the } \\
\text { time limit for appeal starts to run from the day of serving, } \\
\text { and the complaint of the other side against the rejoinder), } \\
\text { - on the defendant who has a defence counsel (the } \\
\text { indictment, the judgement, all decisions for which the time } \\
\text { limit for appeal starts to run from the day of serving, and the } \\
\text { complaint of the other side against the rejoinder are served } \\
\text { on the defence counsel and the defendant), } \\
\text { - on the private prosecutor and the injured party acting as } \\
\text { private prosecutor (a summons to bring private charges or } \\
\text { indictment and summons to the main hearing, decisions for } \\
\text { which the time limit for appeal starts to run from the day } \\
\text { of serving, and the complaint of the other side against the } \\
\text { rejoinder). }\end{array}$ \\
\hline $\begin{array}{c}\text { ZPP } \\
\text { Art. } 142\end{array}$ & $\begin{array}{l}\text { An action, a court's decision subject to appeal, an } \\
\text { extraordinary legal remedy, the order for payment of the } \\
\text { court fees for the motion, a summons to the party to a } \\
\text { settlement hearing or to the opening hearing. }\end{array}$ \\
\hline
\end{tabular}

Source: own analysis, 2018.

The above comparison shows that the addressees that need to be served in person vary considerably depending on the law or type of procedure. For example, according to the ZUP, personal service applies to any person for whom the document is intended, and no distinction is made as to the role of the party in the proceedings. These persons are served decisions, procedural decisions and other documents from the serving of which a time limit to file a legal remedy begins to run, or the service entails an obligation for the addressee to do or allow something or acquire a certain right. The ZKP distinguishes between personally serving on the defendant or on a private prosecutor and the injured party, while additionally defining the cases of service on the defendant depending on whether or not they have a defence counsel. According to the above, the defendant is served all documents, while the private prosecutor and the injured party as the prosecutor are only served a list of documents. 
According to the ZPP, the parties to the proceeding are served all those documents that affect their status of a party, similarly to the ZUP (action, court's decision subject to appeal, extraordinary legal remedy, order for payment of the court fees for the motion, summons to the party to a settlement hearing or to the opening hearing).

A comparison of personal service under the abovementioned laws shows that the ZUP and the ZPP are quite similar, whereas personal serving under the ZKP is rather specific and more complex. The latter involves a particular type of relationship between the State and the individual, where the consequences for the individual are much more severe than under the other two laws. In criminal proceedings, the focus is on the protection of the constitutionally presumed innocence, meaning that a person is innocent until found guilty by a final judgement.

\subsection{Fiction of service}

According to Kovač, Rakar and Remic, the ZUP establishes fiction of service in cases of unsuccessful personal service on the addressee (Art. 87), service by public notification (Articles 94, 96 and 96a) and refusal of acceptance (Article 95). In order to establish fiction of service, however, it is essential that the addressee is aware of the consequences if the document is not taken over within 15 days of the day the note was left. Therefore, fiction of service cannot arise if the server leaves in the places specified only a note stating that the addressee must report to the postal office. According to the above three authors, fiction of service is based on the actual acknowledgement by the party of the obligation to take over the document and of the consequences of not doing so within the period set for each particular type of service (Kovač et al., 2012, pp. 180-181).

Under the ZKP, fiction of service is regulated differently than under the ZUP, which is understandable considering the different status of the parties in court proceedings (defendant, defendant with a defence counsel, private prosecutor, injured party acting as private prosecutor, etc.) and the legal consequences for the parties arising from the judgments. ${ }^{5}$ According to the ZKP, fiction of service is established when the court is unable to serve the document ${ }^{6}$ at the address of the defendant (the defendant is not found at this address or has changed the address without notifying it); in such a case, the court posts the document on the court board and after eight days it is deemed that valid service has been effected (ZKP, Article 120). In a similar way, the court serves on the private prosecutor, the injured party acting as

5 Article 126 of the ZKP provides that in cases not covered by the provisions of the ZKP, serving of documents is effected according to the provisions applying to civil procedure; which probably means that even in criminal proceedings the court can, in certain cases, establish fiction of service.

6 In such a manner, it may serve other decisions for which the time limit for appeal starts to run from the day of serving or the complaint of the other side against the rejoinder, but may not serve a ruling on the issue of a punitive order, a ruling on prison sentence, etc. 
private prosecutor and their legal representative when the document cannot be served on their hitherto address (ZKP, Article 121). Article 122 of the ZKP provides that when the recipient refuses to sign the proof of service, the server makes a note thereof indicating the date of service, whereby the service is considered effected. However, this is not the same fiction of service as provided by the ZUP.

Horvat argues that if the addressee does not take delivery of the document within the time set, service is deemed not effected. In such a case, the court may, subject to certain conditions, post some of the documents on the court board and only then, after eight days, service is deemed to have been effected. The ZKP does not contain a provision such as some other regulations (ZUP and ZPP), whereby even if the addressee does not take delivery by the set deadline, service is deemed to have been effected (Horvat, 2004, page 262).

Horvat points out that serving a decision by posting it on the court board implies legal fiction, therefore the defendant cannot prove that he/she was not aware of its content. Serving a judgement by posting it on the court board is permissible only if the defendant failed to notify a change of address, i.e. when the defendant knows that criminal proceedings were initiated against him/her and was warned that he/she was obliged to report to the court every change of address. Hence, this manner of service is not appropriate for judgements on the issue of punitive orders, since such judgements are issued without hearing the defendants and without warning them of their duty to report to the court any change of address (Horvat, 2004, pp. 264-265).

According to the Supreme Court of Slovenia, legal fiction means that a fact that certainly does not exist is considered true. Thus, fiction of service applies as a special legal institution to determine the moment of the beginning of the time limit for bringing an action (or filing a request to initiate proceedings) or filing a legal remedy, or for the creation of other legal consequences in a number of proceedings, and must therefore be implemented in the same manner although the laws governing these procedures do not regulate it in the same way. ${ }^{7}$

The ZPP (Article 142) regulates fiction of service very similarly to the ZUP, whereby under the ZUP service is considered effected on the day of expiry of 15 days, whereas under the ZPP it is considered effected after the expiry of 15 days.

7 Legal opinion by the Supreme Court of Slovenia of 14 January 2015. 
Table 2: Fiction of service

\begin{tabular}{|c|c|}
\hline $\begin{array}{c}\text { Procedural } \\
\text { law }\end{array}$ & Fiction of service when service cannot be effected personally \\
\hline $\begin{array}{c}\text { ZUP } \\
\text { Art. } 87\end{array}$ & $\begin{array}{l}\text { If the addressee fails to take delivery of the document within } 15 \text { days, } \\
\text { service is considered effected as of the day when this time limit expires. } \\
\text { After the expiry of such time limit, the server leaves the document } \\
\text { referred to in paragraph one of this Article in the addressee's house } \\
\text { letterbox or the detached letterbox. If the party has no letterbox or if it } \\
\text { cannot be used, the server shall return the package to the sender. The } \\
\text { written note must contain information on the consequences of such } \\
\text { service. }\end{array}$ \\
\hline \multirow{4}{*}{$\begin{array}{c}\text { ZKP } \\
\text { Art. } \\
120-121\end{array}$} & $\begin{array}{l}\text { If the defendant (without defence counsel) is to be served a judgement } \\
\text { by which he is sentenced to imprisonment and the judgement cannot be } \\
\text { delivered to his hitherto address, the court appoints a defence counsel } \\
\text { ex officio until the new address of the defendant is obtained. The court } \\
\text { determines a time limit within which the appointed defence counsel is } \\
\text { required to study the file, after which it delivers the judgement to him } \\
\text { and continues proceedings. Where a document to be delivered is a de- } \\
\text { cision for which the time limit for appeal starts to run from the day of } \\
\text { serving, or a complaint of the other side against the rejoinder, the court } \\
\text { posts the decision or the complaint on the court board and after a lapse } \\
\text { of eight days it is considered that the serving has been effected. }\end{array}$ \\
\hline & If the defendant has a defence counsel, the court delivers the docu- \\
\hline & $\begin{array}{l}\text { ments from the second paragraph of this Article to the defence counsel } \\
\text { and to the defendant according to the provisions of Article } 119 \text { of the } \\
\text { ZKP. In that case, the time limit for filing a legal remedy or for a rejoin- } \\
\text { der starts to run from the last serving. If the decision or the complaint } \\
\text { cannot be served on the defendant because he failed to report the } \\
\text { change of address of residence, the decision or the complaint is posted } \\
\text { on the court board and after eight days the serving is considered to } \\
\text { have been effected. }\end{array}$ \\
\hline & $\begin{array}{l}\text { If a summons to bring private charges or an indictment and a summons } \\
\text { to the main hearing cannot be delivered to the addresses of the private } \\
\text { prosecutor or the injured party acting as a prosecutor, the court posts } \\
\text { that summons, decision or complaint on the court board and after eight } \\
\text { days it is considered that the serving has been effected. }\end{array}$ \\
\hline $\begin{array}{c}\text { ZPP } \\
\text { Art. } 142\end{array}$ & $\begin{array}{l}\text { If the recipient fails to collect the documents within } 15 \text { days, the service } \\
\text { is considered to have been effected after the expiry of such time limit, } \\
\text { and the addressee must be warned thereof in the note referred to in } \\
\text { the preceding paragraph. After the expiry of the said time limit, the } \\
\text { server leaves the documents referred to in the preceding paragraph in } \\
\text { the addressee's house letterbox or the detached letterbox. If the party } \\
\text { has no letterbox or if it cannot be used, the documents are returned to } \\
\text { the court and the addressee is informed thereof with a note. }\end{array}$ \\
\hline
\end{tabular}

Source: own analysis, 2018. 
Fiction of service means that service has been effected although there is a possibility that the addressee has not been informed of the content of the document despite such being placed in the letterbox. The ZUP and the ZPP consider that fiction of service has been effected even if the addressee has not arranged or does not have a house letterbox at all, and even though the document has been returned to the decision-making body (see Table 3).

Fiction of service has particularly important consequences when it comes to documents that should be served on the party in person. Fiction of service presupposes that the party has not received the documents from the court. Nevertheless, legal consequences arise (e.g. deadline for responding to an action, deadline for filing a complaint or an extraordinary legal remedy, failure to pay a court fee within a specified time frame that leads to fiction of withdrawal of the action), which may be very difficult for the party. For this reason, some experts ask themselves whether such a fiction of service jeopardises the constitutional right to judicial protection or equality before the court (thus jeopardising the constitutional rights under Articles 22 and 23 of the Constitution) (Ude, 2002, p. 195).

As regards fiction of service, an interesting case is Nunes Dias v. Portugal, where the European Court of Justice confirmed that it was not necessarily contrary to Article 6 of the ECHR if the Court served the judgement under the rules on the fiction of service (by posting it on the court board). Such practice was admissible in that specific case since the court first performed reasonable inquiries with the help of the Police in order to find out the exact place of residence of the defendant. Only after this could not be established, service was effected by posting the judgement on the court board and an ad in the national newspaper. In fact, according to national law, the protection of the defendant is ensured by the fact that, within five years from the final decision or in the enforcement procedure, he/she can dispute the regularity of service (Galič, 2004, pp. 175-176).

Regarding fiction of service, Galič argues that it is wrong that the system of service under Articles 141 and 142 of the ZPP in Slovenia is often considered fiction of service. When served in a letterbox, there is a high degree of probability that the addressee acquaints himself/herself with the document. According to Galič, this is not fiction but a very real assumption. On the other hand, fictitious service is serving on a legal entity at its registered address if it is apparent to the server that the legal entity does not actually operate there. True fiction of service (by posting on the information board) is provided by Article 145 of the ZPP only if the defendant changes residence during the proceeding and fails to report this to the court (Galič \& Betteto, 2011, pp. 140-141). 
It seems that fiction of service and the related deadlines will continue to be a bone of contention between theoreticians and practitioners. The point of the article is that serving by fiction should be unified in all areas where such applies, since only uniform legislation can lead to uniform practice. However, it is unacceptable that the provisions on the fiction of service under the ZUP and the ZPP are interpreted uniformly, on grounds that "the problem is in the details".

\subsection{Special examples of service - service abroad ${ }^{8}$}

Service abroad is organised in different ways at the international level. Documents (acts, decisions, judgements, summons, etc.) can be served, for example, through diplomatic channels. Such a manner of serving can be very complex and time consuming because of the large number of bodies involved. Service is also possible on the basis of a bilateral convention concluded between two countries; in such case, serving is effected, as a rule, through the competent ministries of justice. Slovenia has concluded bilateral treaties on legal aid in civil and criminal matters with Croatia, Macedonia, Russia and Turkey (these treaties also include provisions on cross-border service). Likewise, service can be effected on the basis of multilateral conventions (the Hague Convention of 1 March 1954 on civil proceedings, the Hague Convention of 15 November 1965 on the service abroad of judicial and extrajudicial documents in civil or commercial matters).

8 See European Commission, 2013. 
Table 5: Service abroad

\begin{tabular}{|c|c|}
\hline $\begin{array}{c}\text { Procedural } \\
\text { law }\end{array}$ & Service abroad \\
\hline $\begin{array}{c}\text { ZUP } \\
\text { Art. } 89 \\
\text { and } 92\end{array}$ & $\begin{array}{l}\text { - If the party or his or her statutory representative is abroad and } \\
\text { does not have an authorised person in the country, they shall } \\
\text { be required, on the serving of the first document, to appoint } \\
\text { an authorised person or authorised receiver within a specified } \\
\text { time limit, and shall be informed that an authorised receiver or } \\
\text { temporary representative shall be appointed to them ex officio if } \\
\text { they do not themselves appoint an authorised person within the } \\
\text { time limit determined. } \\
\text { - Natural persons and legal persons abroad may be served directly } \\
\text { or through diplomatic channels, unless otherwise provided by } \\
\text { treaty. }\end{array}$ \\
\hline $\begin{array}{c}\text { ZKP } \\
\text { Art. } 124\end{array}$ & $\begin{array}{l}\text { - Serving on Slovenian nationals abroad shall be effected via dip- } \\
\text { lomatic or consular missions of the Republic of Slovenia, provid- } \\
\text { ed that the foreign country in question does not oppose such } \\
\text { manner of serving and that the recipient agrees to accept it. The } \\
\text { authorised person of the diplomatic or consular mission shall } \\
\text { sign the serving form as the server if the document is delivered } \\
\text { in the premises of the mission; if the document is sent by mail he } \\
\text { shall confirm it on the serving form. }\end{array}$ \\
\hline $\begin{array}{c}\text { ZPP } \\
\text { Art. } 135 \\
\text { and } 146\end{array}$ & $\begin{array}{l}\text { - If a document is to be served on a person or institution based in } \\
\text { a foreign state or on a foreign citizen enjoying immunity, service } \\
\text { shall be effected through diplomatic channels, unless otherwise } \\
\text { provided by a treaty or the ZPP. Documents can be served on } \\
\text { a citizen of the Republic of Slovenia residing in a foreign state } \\
\text { through a consular or diplomatic representative. Such service } \\
\text { shall be valid only if the person to be served is willing to accept } \\
\text { such. } \\
\text { - Upon filing of the action, the plaintiff shall appoint a person au- } \\
\text { thorised to accept the service in the Republic of Slovenia. If the } \\
\text { plaintiff fails to appoint such person upon filing of the action, } \\
\text { the court shall appoint to the plaintiff, and to his expense, a tem- } \\
\text { porary representative authorised to accept the service, and shall } \\
\text { through such temporary representative order him to appoint a } \\
\text { person authorised to accept service in a specified period of time. } \\
\text { If the plaintiff fails to do so, the court shall reject the action. } \\
\text { - Upon the first service of documents, the court shall order the } \\
\text { defendant to appoint a person authorised to accept service } \\
\text { in the Republic of Slovenia. If the defendant fails to do so, the } \\
\text { court shall appoint to defendant, and to his expense, a tempo- } \\
\text { rary representative authorised to accept service, and shall in- } \\
\text { form the defendant thereof. }\end{array}$ \\
\hline
\end{tabular}

Source: own analysis, 2018. 
Galič emphasises that in order to regulate cross-border service, account must be taken of the fact that the manners of serving in individual countries, including within the EU, vary considerably. In some countries (e.g. Slovenia), service is a task of the court (usually by mail). In other countries, it is up to the party to ensure that a document will reach the opposite party, and the court is only informed that service has been effected (therefore, action to the court is brought only after it is served on the opposite party, or the court defines, at the time the plaintiff brings action, a period within which the judgement should be served). In some countries, serving is the task of professional private servers. There are also significant differences in terms of substitute service and service to the house letterbox, as well as in terms of the possibility of "fictitious" service when the defendant cannot be found (Galič, 2010, p. 52).

The comparison clearly shows that individual laws regulate service abroad rather specifically; according to the ZUP, documents can be served directly, according to the ZKP they are served through diplomatic missions, while according to the ZPP they can be served through diplomatic missions, based on Regulation (EC) No. 1393/2007, or otherwise. The author's opinion is that service abroad should be simplified and specific situations regulated in some other manner.

\section{Analysis of Slovenian Case Law Regarding Service}

\subsection{Methodological basis}

The research analysed the judgments of the Supreme Court of Slovenia in terms of service in administrative, criminal and civil matters between 2013 and $2016 .^{9}$

75 Supreme Court judgments were examined, of which 28 from the administrative department, 34 from the criminal law department, and 13 from the civil department.

This analysis was based on the judgments of the Supreme Court that represent unified case law and thus ensure judicial protection of individuals or other entities against authoritative actions of the administration. This is also suggested by Kerševan, stating that judicial protection is guaranteed against every authoritative action by the administration, with the court being the final arbitrator on the meaning and content of administrative law used as a basis for assessing the legality (legal regularity) of the administration's actions. (Kerševan, 2008, p. 1137).

9 The time frame 2013-2016 was chosen due to the high number of cases in such regard and because of the significance of the legal opinion by the Supreme Court of Slovenia of 14 Januагу 2015. 


\subsection{Quantitative analysis of the judgements of the Supreme Court by type of procedure}

The analysis of the judgments of the Supreme Court in relation to service shows (Table 6) that between 2013 and May 2016, a total of 76 judgments were issued in relation to service. The search in case-law actually showed 51 cases related to 'serving' and 101 cases related to 'service' in connection to the ZUP, ZKP and ZPP, yet a further review revealed that some cases were reported more than once. In addition, following a substantive analysis of the judgments, some were excluded because they did not relate to the research topic.

Table 6: Number of Supreme Court judgements concerning service and applicants

\begin{tabular}{|l|c|c|c|}
\hline \multicolumn{1}{|c|}{ Department } & $\begin{array}{c}\text { Number of } \\
\text { judgements }\end{array}$ & Party & State \\
\hline Administrative & 29 & 29 & 0 \\
\hline Criminal law & 34 & 26 & 8 \\
\hline Civil & 13 & 13 & 0 \\
\hline Total & 76 & 68 & 8 \\
\hline
\end{tabular}

Source: own analysis, 2018.

When analysing the parties that initiated the proceedings before the Supreme Court, an interesting conclusion could be drawn, namely that in 68 cases proceedings were initiated on request of the parties and in eight cases on the initiative of a representative of the State. Interestingly, even in cases where proceedings before the Supreme Court were initiated by a representative of the State (in our case, the Supreme State Prosecutor), they were initiated in favour of the party/defendant, according to Article 421 of the ZKP. Table 6 also indicates that as regards the applicants, service is regulated slightly more specifically under the ZKP than under the other two systems.

Table 7: Supreme Court decisions concerning service

\begin{tabular}{|l|c|c|c|}
\hline Procedural law & $\begin{array}{c}\text { Number of } \\
\text { judgements }\end{array}$ & $\begin{array}{c}\text { In favour of } \\
\text { the party }\end{array}$ & $\begin{array}{c}\text { In favour of } \\
\text { the State }\end{array}$ \\
\hline ZUP & 26 & 8 & 18 \\
\hline ZKP & 26 & 5 & 21 \\
\hline ZPP & 24 & 7 & 17 \\
\hline Total & 76 & 20 & 56 \\
\hline
\end{tabular}

Source: own analysis, 2018.

10 In all eight cases, the Supreme State Prosecutor filed a request for protection of legality in favour of the defendant (ZKP, Article 421). 
Table 7 shows the decisions of the Supreme Court by procedural law. In order to obtain the above data, individual elements of service were examined depending on the procedural law under which service was effected. Data reveal that in 2013-2016, 26 judgments related to service under the ZUP, 26 to service under the ZKP, and 24 to service under the ZPP. In 20 cases, the Supreme Court decided in favour of the party, which means that the state authority made a mistake in service. Here are some examples of incorrect conduct of a state body under the ZUP ${ }^{11}$ : Judgment IV Ips 144/2013 of 21 January 2014, where the Court did not serve the summons on the attorney although she was authorised by the perpetrator and the court was informed thereof; Judgment IV Ips 98/2014 of 17 March 2015, where the court did not send a summons on the offender to the address of permanent residence but rather to a temporary address, although the address of permanent residence was indicated in the central population register as the address for service; Judgment IV Ips 17/2014 of 18 March 2014, where the court wrongly concluded that the complaint was sent too late because it was mailed through an authorised Petrol service station instead of the post office, but did not take into account that Petrol d.d. had a contract with the Slovenian Post allowing registered mail to be mailed through authorised Petrol stations. Examples of incorrect service under the ZKP: Judgment I Ips 15883/2010-128 of 14 January 2016, where the server acted inappropriately since he could have effected service in the manner prescribed in Article 123 of the ZKP only if the addressee refused to accept the documents or would not want to accept them without a lawful reason; Judgment XI Ips 9660/2009-341 of 11 September 2014, where at the time of serving the indictment the defendant could not be at the address for service in Slovenia since he was detained in Croatia and was later unable to leave the territory of Croatia. Examples of incorrect service under the ZPP: Decision I Up 148/2015 of 30 September 2015, where the server left the documents on a desk at the office and did not serve them on the person authorised to accept mail; likewise, it is not correct to state that someone who refuses to accept mail by phone refuses to accept in accordance with the provisions of the ZPP; Decision I Up 189/2015 of 10 September 2015, where service at the debtor's address was incorrect since it should have been effected at the address of the insolvency administrator as an authorised person.

The cases presented above show that the system of service in Slovenia is very complex and non-systematic. A practical example thereof is minor offence bodies having to act in accordance with both the ZUP and the ZP-1 when serving minor offence acts. Moreover, in 56 cases, the Supreme Court ruled that the state body correctly implemented the provisions on service under a particular procedural law.

11 According to Articles 58 and 67 of the Minor Offences Act (ZP-1), the provisions of the ZUP relating to service apply mutatis mutandis also in minor offence proceedings. However, Article 140 of the ZP-1 provides that a written ruling on a minor offence is served on the defendant, the defence counsel, the defendant's legal representative, the owner of seized property, and on the proposer, i.e. on all the above. 
The analysis of the judgements shows that the number of cases by individual departments of the Supreme Court (administrative, criminal law, civil) does not match the number of cases under procedural laws (ZUP, ZKP and ZPP). This means that there are situations where, for example, the criminal law department deals with service under the ZUP or the ZPP, or the civil department deals with service under the ZUP. The initial assumption was that service under a particular procedural law was consistently effected only under such law, but this is not the case.

Table 8: Supreme Court decisions concerning the elements of service

\begin{tabular}{|l|r|r|r|r|}
\hline \multicolumn{1}{|c|}{ Element of service } & ZUP & ZKP & ZPP & Total \\
\hline Fiction of service & 16 & 8 & 9 & 33 \\
\hline Serving on authorised person/defence counsel & 23 & 7 & 9 & 39 \\
\hline Change of address/address for service & 2 & 11 & 4 & 17 \\
\hline Refusal of acceptance & 0 & 4 & 1 & 5 \\
\hline On specific persons & 0 & 1 & 0 & 1 \\
\hline Electronically/by fax & 0 & 6 & 1 & 7 \\
\hline Other & 6 & 6 & 3 & 15 \\
\hline
\end{tabular}

Source: own analysis, 2018.

Table 8 shows which elements of service were dealt with at the Supreme Court. It needs to be noted here that certain judgments contained several elements of service, since, for example, a judgment may have involved fiction of service, change of address, and refusal of acceptance at the same time. The analysis showed that the most challenged elements were service on authorised person/defence counsel (39 cases), fiction of service (33 cases), and change of address/address for service (17 cases).

The results of the analysis suggest that, by challenging the above elements of service, the parties wished to alter the decisions of the state bodies made to their prejudice, thereby misusing the legal remedies in order to also misuse the provisions on service. Interestingly, as regards service on authorised person or defence counsel, the parties often point out that service was not effected properly, i.e. not on the person actually authorised to accept the documents. Moreover, they often argue (especially in the field of criminal law) that their defence counsel was not informed of the documents or that the party was wrongly served. Regarding fiction of service, the parties most often criticise the fact that service is considered effected after the expiry of the deadline for taking delivery of the documents when the server does not find the party at the address for service (in criminal proceedings, such service is effected by posting on the information board), and the incorrect counting of the deadline for filing a complaint. As regards the change of address, the parties most often dispute the fact that they are served at an address where 
they are not present although they have not reported a change of address, as they are bound to do under the applicable procedural law.

The analysis shows that the institution of service is very vulnerable to misuses by participants in the proceedings when they wish to turn the decision of a state (administrative or judicial) body to their favour. Considering the number of cases solved in favour of the State ( 56 cases or $74 \%$ of the total), it can be concluded that the plaintiffs are rather unfamiliar with the institution of service, the elements of service, and the legal consequences arising therefrom.

\subsection{Analysis of selected Supreme Court and Constitutional Court judgements regarding service}

The importance of fiction of service in terms of the protection of the rights of the parties is demonstrated by the legal opinion of the Supreme Court of Slovenia of 14 January 2015, adopted with a view to unifying case law as regards the beginning of fiction of service in all proceedings where the provisions on fiction of service apply pursuant to Article 87 of the ZUP or Article 142 of the ZPP, when the deadline for service expires on a Saturday, a Sunday, a national holiday which is a work-free day, or another work-free day in Slovenia. According to the opinion of the Supreme Court, the acceptance of a document at the post office that is to be effected by a party is not a procedural action to be carried out with the body (administrative body or court) that conducts the procedure. In fact, paragraph two of Article 101 of the ZUP expressly stipulates: "If the last day of the time limit coincides with a Sunday or a national holiday of the Republic of Slovenia or a work-free day in the Republic of Slovenia or some other day on which the authority where a procedural action is to be performed does not operate, the time limit shall expire on the end of the next working day". However, the provision of paragraph four of Article 111 of the ZPP is different: "If the last day of the period happens to be a Saturday, Sunday or a holiday provided as such by the Public Holidays Act, the time period shall expire on the next working day". The Supreme Court argues that it is necessary to ensure equal treatment of the parties who take delivery of the documents and those who are subject to fiction of service. In most major cities, mail is delivered also on Saturdays. This means that if the party is served the document on a Saturday or on a day before a holiday, the time limit for bringing action or filing legal remedies begins, or other legal consequences arise, on a Sunday or a holiday. On the other hand, if a person is left a note of service in the letterbox and fiction of service should arise on a Saturday (this is especially important for locations where mail is not delivered on Saturdays), a Sunday or a holiday that is a work-free day, fiction service following the provisions on the expiry of procedural deadlines under the ZUP or ZPP would actually arise only on the next working day, placing such person in an unacceptably privileged position.

The Constitutional Court dealt with a case in which the Higher Court rejected a complaint for being filed too late, since in the complainant's case fiction of service arose according to paragraph four of Article 142 of the ZPP and the rule 
referred to in paragraph four of Article 111 ZPP could not be taken into account. This could only apply for an addressee who actually accepted the document, while an addressee who was fictitiously served would not be entitled to such an extension as referred to in paragraph four of Article 111 of the ZPP. In the case of fiction of service, the deadline expires on the last day, regardless of whether it falls on a Saturday, a Sunday, a holiday, or other work-free day. In his complaint against the Higher Court, the complainant alleged that the subsequent enforcement of the legal opinion of the Supreme Court led to an actual change of the legislation, interference with legal certainty and predictability, and unequal treatment in cases where a document is served by regular mail and cases where it is served by fiction. He stated, inter alia, that he acted as allowed by law until the Supreme Court's legal opinion, which he only learned about after receiving the decision, against which he filed the complaint.

With regard to the complainant's allegations about interference with legal certainty and predictability of the complainant's situation, the Constitutional Court replied that the law and the conduct of all state bodies must be predictable, as this is required by legal certainty (the court may not treat a party unequally by deciding in his/her case differently than in other similar cases). Moreover, Article 2 of the Constitution refers to the competing principle of the law adapting to social conditions, respecting human rights and fundamental freedoms (the right to equal protection of rights under Article 22 of the Constitution does not mean that case law should not change over time). The Constitutional Court went on by explaining that, no matter how clear a rule of law was, it became the subject of (judicial) interpretation. Yet, to its view, also the development of case-law should be predictable to the extent that the addressees of legal norms could adapt to legal developments resulting from changing case law. The court therefore needs to determine whether the individual could reasonably anticipate the conduct required from him by the changed (new) case law. In doing so, it should take into account the law applying in the given moment as well as the case law applying before the new legal rule was adopted, as well as other important circumstances, such as whether case law was subject to criticism in legal literature, the consequences of the application of the new rule for the party, in particular the positive or negative effect on his legal position, etc. Therefore, in that particular case, the Constitutional Court decided that - given that the complainant had filed the complaint before the described change of case law resulting from the legal opinion - the position of the Higher Court following the changed case law could not have been reasonably predicted.

\section{Discussion and Recommendations}

Upon comparing procedural laws and their subject matter, the fundamental principles and the objectives thereof, it becomes clear that the institution of service must be regulated differently for different procedural processes. Nevertheless, the analysis of the judgements (e.g. the legal opinion of the 
Supreme Court of 14 January 2015) and procedural law (e.g. the ZKP in certain cases refers to the ZPP and ZUP) in relation to service under the ZUP, ZKP and ZPP leads to conclude that some elements of service could be unified for all three procedural areas. In fact, in some cases, even the procedural laws themselves refer to other procedural laws, which leads to confusion and lack of clarity in the work of state bodies.

Each of the legal areas under consideration has its specifics, which confirm that the institution of service should be regulated differently in a particular procedural law. Still, there are certain similarities between them, which speak in favour of a common regulation of certain elements of service.

The research also revealed that the interpretation of service in individual procedural laws is not uniform - a good example thereof is the legal opinion of the Supreme Court of 14 January 2015, which had to set uniform practice in terms of counting the deadlines in the event of fiction of service. Nonetheless, case law still differs, which is confirmed by the judgment of the Constitutional Court Up-164/15-14 of 18 February 2016, adopted one year after the published legal opinion of the Supreme Court. With regard to the complainant's allegations about interference with legal certainty and predictability of the complainant's situation, the Constitutional Court replied that the law and the conduct of all state bodies must be predictable, as this is required by legal certainty (the court may not treat a party unequally by deciding in his/her case differently than in other similar cases). Moreover, Article 2 of the Constitution refers to the competing principle of the law adapting to social conditions, respecting human rights and fundamental freedoms (the right to equal protection of rights under Article 22 of the Constitution does not mean that case law should not change over time). The Constitutional Court went on by explaining that, no matter how clear a rule of law was, it became the subject of (judicial) interpretation. Yet, to its view, also the development of case law should be predictable to the extent that the addressees of legal norms could adapt to legal developments resulting from changing case law. The court therefore needs to determine whether the individual could reasonably anticipate the conduct required from him by the changed (new) case law. In doing so, it should take into account the law applying in the given moment as well as the case law applying before the new legal rule was adopted, as well as other important circumstances, such as whether case law was subject to criticism in legal literature, the consequences of the application of the new rule for the party, in particular the positive or negative effect on his legal position, etc. Therefore, in that particular case, the Constitutional Court decided that - given that the complainant had filed the complaint before the described change of case law resulting from the legal opinion - the position of the Higher Court following the changed case law could not have been reasonably predicted.

The analysis reveals that in Slovenia, the rules on service are such that even administrative bodies sometimes do not know under which law and how to order service. Hence, the rules of criminal procedure interfere with the provi- 
sions of the ZUP in minor offence cases, the ZKP sometimes refers to the ZUP and the ZPP, and there are also other specific features regarding service, for example, in tax procedures.

Upon comparing procedural laws and their subject matter, the fundamental principles and the objectives thereof, it becomes clear that the institution of service must be regulated differently for different procedural processes. Nevertheless, the analysis of the judgements (e.g. the legal opinion of the Supreme Court of 14 January 2015) and procedural law (e.g. the ZKP in certain cases refers to the ZPP and ZUP) in relation to service under the ZUP, ZKP and ZPP leads to conclude that some elements of service could be unified for all three procedural areas. In fact, in some cases, even the procedural laws themselves refer to other procedural laws, which leads to confusion and lack of clarity in the work of state bodies. Therefore, the author believes that comprehensive changes of some elements of legislation and further concern for its implementation are necessary.

\section{Conclusion}

The aim of the article was to present the differences of service under a particular procedural law and the consequences of a particular regulation for the parties in the proceedings.

The empirical part of the analysis, focusing on the judgements of the Supreme Court of Slovenia, was intended to determine whether the differences between the ZUP, ZKP and ZPP are such that these laws should have their own provisions on service, or should these provisions rather be included in a single regulation. The analysis of Supreme Court judgments revealed that the issue is not as unambiguous as it seems. Although certain elements of service could indeed be unified, at least as far as the ZUP and ZPP are concerned, there are some exceptions that call for a specific regulation of service. In any case, it is up to the legislature to decide whether to unify the provisions on service, thus simplifying it, or to preserve the existing situation which, however, is no longer manageable in terms of an easy understanding of the provisions on service. Based on the analysis of the judgements, it turned out that the institution of service is subject to constant misuses by citizens i.e. participants in the proceedings. Misuse is all the more common, the more complicated is the system of service. An unspecified and unclear article regulating service can lead to different interpretations which individuals with a good knowledge of law efficiently take advantage of.

The comparison of relevant procedural laws reveals that there is considerable confusion as regards service. Service in Slovenia is too rigid and complicated, and the differences under individual procedural laws are significant (the provisions are even drafted differently, although they are supposed to be interpreted in the same way). It also turned out that the authorities understand the same provisions in a diametrically opposite way and therefore also act 
differently. The process of service is further complicated by the servers (postal services, authorised servers, bodies serving directly), which leads to errors and legitimate claims by the parties to annul, renew or otherwise resolve the matter. Although the judgments of the Supreme Court supposedly constitute case law, it appears that the authorities do not follow the judgments of the Supreme Court when serving, which may, inter alia, be attributed to the lack of knowledge of case law, the authorities being overly self-confident, or other possible reasons.

The author sees the results of the research as a possible contribution to the modernisation of the ZUP, ZKP and ZPP in a way that the legislature will be more attentive to certain inconsistencies and contradictions and will adopt laws that will be more coherent when it comes to service, while also taking into account the specifics of individual procedural laws. 


\section{References}

Androjna, V. and Kerševan, E. (2006). Upravno procesno pravo. Ljubljana: GV Založba.

Breznik, J., Štucin, Z. and Marflak, J. (2008). Zakon o splošnem upravnem postopku s komentarjem. Ljubljana: GV Založba.

Contentious Civil Procedure Act (ZPP) (1999). Official Gazette of RS, No. 26/99 and amendments.

Criminal Procedure Act (ZKP) (1994). Official Gazette of RS, No. 63/94 and amendments.

European Commission (2013). Report from the Commission to the European Parliament, the Council and the European Economic and Social Committee on the application of Regulation (EC) No 1393/2007 of the European Parliament and of the Council on the service in the Member States of judicial and extra judicial documents in civil or commercial matters (service of documents). At: <http://eur-lex.europa.eu/>, accessed 10 August 2018.

Galič, A. (2004). Ustavno civilno procesno pravo. Ljubljana: GV Založba.

Galič, A. (2010). Vročanje sodnih pisanj v tujino v civilnih in gospodarskih zadevah. In L. Ude (ed.), Pravni letopis. Ljubljana: Institute for Comparative Law, pp. 51-72.

Galič. A. and Betetto, N. (2011). Evropsko civilno procesno pravo I - čezmejno izvajanje dokazov, čezmejno vročanje, evropski izvršilni naslov, evropski plačilni nalog, evropski spor majhne vrednosti. Ljubljana: GV Založba.

General Administrative Procedure Act (1999). Official Gazette of RS, No. 80/99 and amendments.

Horvat, Š. (2004). Zakon o kazenskem postopku s komentarjem. Ljubljana: GV Založba.

Jerovšek, T., Trpin, G., Bugarič, B., Horvat, M., Kerševan, E., Kovač, P., Mužina, A., Pličanič, S., Vesel, T. and Virant, G. (2004). Zakon o splošnem upravnem postopku s komentarjem. Ljubljana: Institute for Comparative Law.

Jerovšek, T. and Kovač, P. (2010). Upravni postopek in upravni spor. Ljubljana: Fakulteta za upravo.

Kerševan, E. (2008). Vladavina prava in upravno pravo. Podjetje in delo, 34 (6-7), pp. 1131-1140.

Kerševan, E. and Androjna, V. (2017). Upravno procesno pravo: upravni postopek in upravni spor. Ljubljana: GV Založba.

Kovač, P. and Remic, M. (2008). Aktualne dileme osebnega vročanja po ZUP. Pravna praksa, 27(37), pp. 8-10.

Kovač, P., Rakar I. and Remic, M. (2012). Upravno-procesne dileme o rabi ZUP 2. Ljubljana: Uradni list Republike Slovenije.

Kovač, P. (2013). Pravica biti slišan v upravnem postopku po slovenski ustavnosodni praksi. Pravnik - revija za pravno teorijo in prakso, 68(3-4), pp. 203-225.

Kovač, P., Remic, M. and Sever, T. (2015). Upravno-procesne dileme 3 v posebnih upravnih postopkih. Ljubljana: Uradni list Republike Slovenije.

Regulation (EC) No 1393/2007 of the European Parliament and of the Council of 13 November 2007 on the service in the Member States of judicial and extrajudicial documents in civil or commercial matters (service of documents), and repealing Council Regulation (EC) No 1348/2000. 
Supreme Court of RS. At <http://www.sodnapraksa.si/>, accessed 10 August 2018.

Selinšek, L. (2007). Kazensko pravo splošni del in osnove posebnega dela. Ljubljana: GV Založba.

Toplak, L. (2002). Civilno pravo. Knjiga 1, Splošni del civilnega prava. Maribor: Faculty of Law of the University of Maribor.

Turk, B., J., Lampe, R., Bošnjak, M. and Teršek, A. (2004). Človekove pravice v pravnih in sodnih postopkih. Ljubljana: Legalia.

Ude, L. (2002). Civilno procesno pravo. Ljubljana: Uradni list Republike Slovenije. Ude, L., Betetto, N., Galič, A., Rijavec, V., Wedam Lukić, D. And Zobec, J. (2005). Pravdni postopek - zakon s komentarjem. Ljubljana: GV Založba, Uradni list Republike Slovenije. 